\title{
Evaluation of a collagen-bioaggregate composite scaffold in the repair of sheep pulp tissue
}

\section{Purpose}

This study aimed to compare the effects of the collagen-BioAggregate mixture (CBA-M) and collagen-BioAggregate composite (CBA-C) sponge as a scaffolding material on the reparative dentin formation.

\section{Materials and Methods}

CBA-C sponge (10:1 w/w) was obtained and characterized by Scanning Electron Microscopy (SEM) and Mercury Porosimetry. Cytotoxicity of the CBA-C sponge was tested by using the L929 mouse fibroblast cell line. Dental pulp stem cells (DPSCs) were isolated from the pulp tissue of sheep teeth and characterized by flow cytometry for the presence of mesenchymal stem cell marker, CD44. The osteogenic differentiation capability of isolated DPSCs was studied by Alizarin Red staining. The cells were then used to study for the compatibility of CBA-C sponge with cell proliferation and calcium phosphate deposition. The effect of CBA-C sponge and CBA-M on the induction of dentin regeneration was studied in the perforated teeth of sheep for the eight-week period. All the analyses were performed with appropriate statistical hypothesis tests.

\section{Results}

CBA-C sponge was found to be biocompatible for DPSCs. The DPSCs seeded on the CBA-C sponge were able to differentiate into the osteoblastic lineage and deposit calcium phosphate crystals in vitro. Reparative dentin formation was observed after the second week in the CBA-C sponge applied group. At the end of eight weeks, a complete reparative dentin structure was formed in the CBA-C sponge applied group, whereas necrotic tissue residues were observed in groups treated with the CBA-M.

\section{Conclusion}

CBA-C sponge represents a better microenvironment for reparative dentin formation probably due to maintaining DPSCs and allowing their osteogenic differentiation and thus calcium phosphate deposition.

Keywords: Direct pulp capping, reparative dentin, collagen sponge, BioAggregate, BioAggregate-sponge composite

\section{Introduction}

Vital pulp therapy is defined as a treatment used to perform an indirect pulp application in teeth with deep caries. It can be applied in two ways; by direct pulp capping or pulpotomy in patients with exposed dental pulp tissue (1). Direct pulp capping is a technique in which the pulp protecting agent is directly applied to the exposed pulp tissue. This treatment is used to protect the pulp tissue against further damage, and it allows the regeneration of the dentin pulp complex (2). Dentin pulp complex protection is achieved by performing a single or multilayer pulp capping between the dental tissue and the restorative material. Dentin pulp com-

\author{
Burak Dayı' (1D, \\ Deniz Sezlev Bilecen ${ }^{2,3}$ (D), \\ Hatice Eröksüz ${ }^{4} \mathbb{D}$, \\ Muhammet Yalçın ${ }^{5}$ (D), \\ Vasıf Hasırci, ${ }^{3,6}$ (D)
}

\begin{abstract}
Presented at: The characterization data of collagenBioAggregate scaffold and histopathological findings of fourth and eighth week of collagen-BioAggregate scaffold group of this study was presented as an oral presentation with the title of "The effect of collagen-Bioaggregate scaffold on perforated dental pulp" on the 21th BaSS Congress, May 12-15, 2016, Banja Luka, Bosnia and Herzegovina.
\end{abstract}

ORCID IDs of the authors: B.D. 0000-0002-5289-438X; D.S.B. 0000-0002-5708-2276; H.E. 0000-0002-8407-5792; M.Y. 0000-0003-2077-521X; V.H. 0000-0002-3698-8861

'Department of Restorative Dentistry, Faculty of Dentistry, Inonu University, Malatya, Turkey

${ }^{2}$ Department of Molecular Biology and Genetics, Faculty of Agriculture and Natural Sciences, Konya Food and Agriculture University, Konya, Turkey

${ }^{3}$ BIOMATEN, METU Center of Excellence in Biomaterials and Tissue Engineering, Ankara, Turkey

${ }^{4}$ Department of Pathology, Faculty of Veterinary Medicine, Firat University, Elazığ, Turkey

${ }^{5}$ Private Practice, Malatya, Turkey

${ }^{6}$ Department of Medical Engineering, Faculty of Engineering, Acibadem University, İstanbul, Turkey

Corresponding Author: Burak Dayı

E-mail: bdayi70@hotmail.com

Received: 10 April 2021 Revised: 4 May 2021 Accepted: 17 May 2021

DOI: 10.26650/eor.2021911441 
plex is protected to prevent damages that occur due to the bacterial invasion resulting from operative procedures, the toxicity of the restorative material, and microleakage. Dentin pulp tissue protection is ensured by recovering the vitality of the pulp (3).

Mineral Trioxide Aggregate (MTA) was introduced by Torabinejad and White as the first calcium silicate based material in the 1990s (4). In the following periods newer modifications, such as BioAggregate (in 2006), Biodentine (in 2009), EndoSequence BC RRM (in 2009) and TheraCal LC (patented in 2008) were reported $(5,6)$. BioAggregate is a biocompatible material, and it is safe to use it in the pulp capping process. It is composed of ceramic particles, and its content is similar to the MTA. It can be used in perforation repair and treatment of vital pulp (7).

Tissue engineering is a multidisciplinary field that applies engineering principles to restore, maintain, and develop the normal functions of organs (8). There are three components of tissue engineering; living cells, carriers of cells (scaffolds), and signal molecules such as growth factors (9).

Scaffolds are three-dimensional networks of synthetic or natural polymers that serve as extracellular matrices for cells for a limited duration. They allow cells to migrate and propagate and are used to create tissue mimics in pre-designed forms and structures. Natural polymers have excellent biocompatibility, whereas synthetic polymers possess controlled physico-chemical properties such as dissolution rate, microstructure, and mechanical strength (10). Various synthetic materials do not satisfy the requirements expected of scaffolds in tissue engineering applications, and therefore, animal-derived natural polymers such as collagen and elastin are preferred over the synthetics to create better carriers (11).

Regeneration of pulp tissue is an important alternative for direct pulp capping to more traditional restorative procedures (12). Dental pulp stem cells (DPSCs), which are being used mainly in tooth regeneration studies, are multipotent stem cells that can be isolated from dental tissue for pulp regeneration. They can differentiate into a variety of cell types, including adipocytes, chondrocytes, osteoblasts, and odontoblasts, while exhibiting more substantial odontogenesis characteristics (13). Therefore, it is important to develop new bioactive materials for managing the dental pulp regeneration.

In this study, collagen and BioAggregate materials were mixed and used either directly or in the form of a sponge as a capping material in sheep teeth with perforated pulp tissues. The aim of this study was to compare the effects of collagen-BioAggregate mixture and collagen-BioAggregate composite sponge on reparative dentin formation within an eight-week period. The null hypothesis of this study was that the collagen-BioAggregate mixture and collagen-BioAggregate composite sponge would have no difference in reparative dentin formation during all weeks studied.

\section{Materials and methods}

\section{Ethical statement}

All the surgical procedures were approved by the Animal Testing Ethics Committee of Firat University, Elazığ, Turkey, with meeting number 2014/9 and decree number 96.

\section{Isolation of DPSCS}

Pulps from sheep teeth $(n=4)$ were minced into 1-2 mm pieces with a scalpel under sterile conditions. The pieces were transferred to T25 tissue culture flasks and kept in growth media (DMEM with $4.5 \mathrm{~g} / \mathrm{L}$ glucose, $10 \%$ fetal bovine serum, $1 \%$ penicillin-streptomycin, $0.4 \%$ amphotericin-B) $\left(5 \% \mathrm{CO}_{2}, 37^{\circ} \mathrm{C}\right)$. The outgrowth of the DPSCs was observed starting from $72 \mathrm{~h}$ and visualized under a phase-contrast microscope (Olympus IX70, Leica, USA). The culture was continued until confluency was reached. Cells were harvested by trypsinization, and the cell pellet was passed through a cell strainer $(70 \mu \mathrm{m})$. The cells were subcultured or frozen in $90 \%$ FBS, 10\% DMSO solution until use.

\section{Characterization of DPSCs by flow cytometry}

The isolated stem cells were analyzed with flow cytometry for the hematopoietic and mesenchymal stem cell markers, CD34 and CD44, respectively (AccuriC6, BD, Germany). Briefly, cells were fixed (PFA,4\%) and washed with FACS buffer (PBS, 1:100 BSA, and 1:1000 sodium azide). The cell pellet was resuspended in primary antibody solutions for stem cell markers CD34 and CD44 (100 $\mu \mathrm{L} ;$ 1:60 CD34 Rabbit Monoclonal, Abcam, ab81289 and $0.02 \mu \mathrm{g}$ CD44 Rat Monoclonal, Abcam, ab119335) and incubated for one $h$ at room temperature $(14,15)$. After washing twice with FACS buffer, the cells were incubated with secondary antibodies $(10 \mu \mathrm{g} / \mathrm{mL}$ Goat anti-rabbit IgG H+L, Alexa 488, Invitrogen A-11034, and Goat anti-rat lgG H+L, Alexa 647, Invitrogen A-21247) for one $\mathrm{h}$ at room temperature. Cell nuclei were stained with Draq5 (1:1000). The cells were washed twice with FACS buffer and resuspended in PBS. Negative controls were unstained cells, isotype control (1:100 Rabbit IgG 488 Isotype control, Abcam ab153686, and $0.02 \mu \mathrm{g}$ Rat IgG 647 Isotype control, Invitrogen R2a21), and only secondary antibody stained cells.

\section{Osteogenic differentiation of DPSCs and maintenance of osteo- blastic cells}

Isolated stem cells were subjected to osteogenic differentiation by using OriCell ${ }^{\mathrm{TM}}$ Mesenchymal Stem Cell Osteogenic Differentiation Medium (Cyagen, USA) according to the manufacturer's protocol. Briefly, $2 \times 10^{4}$ cells were seeded into six-well plates and incubated for 21 days for differentiation medium containing 10\% FBS, 1\% Penicillin-Streptomycin, 1\% L-Glutamine, $1 \% \beta$-Glycerophosphate, 0.2\% Ascorbate, and 0.01\% Dexamethasone. At the end of days 7 and 21, cells were fixed in $4 \%$ PFA for 30 min, washed twice with PBS, and incubated in Alizarin red solution (Cyagen, USA) to stain the calcium deposition. After the osteogenic differentiation process, obtained osteoblasts were maintained in McCoy's 5A medium (Gibco, UK) supplemented with 10\% FBS and 1\% Penicillin-Streptomycin.

Sample preparation and characterization of collagen-BioAggre gate composite sponges

BioAggregate (1.5 mg; DiaDent, Burnaby, BC, Canada) and collagen (15 mg; Sigma-Aldrich, Germany) (10:1, w/w) were mixed and collagen-BioAggregate mixture (CBA-M) sample was prepared. 
BioAggregate (1.5 mg; DiaDent, Burnaby, BC, Canada) and collagen (15 mg; Sigma-Aldrich, Germany) were dissolved in acetic acid $(0.5 \%), 51 \mu \mathrm{L}$ was added to 96 well plates, frozen overnight at $-20^{\circ} \mathrm{C}$, and lyophilized for $8 \mathrm{~h}$ (Labconco, USA) and collagen-BioAggregate composite (CBA-C) sponges (diameter: $1.5 \mathrm{~mm}$, thickness: $1.5 \mathrm{~mm}$ ) were obtained. Dehydrothermal crosslinking (heating at $150^{\circ} \mathrm{C}$ for $24 \mathrm{~h}$ under vacuum) was applied to the sponges and then kept in a desiccator at room temperature until use. Pure collagen sponges were prepared using the same procedure without the addition of the BioAggregate.

Surface topography of pure collagen and CBA-C sponges were studied using Scanning Electron Microscopy (SEM, Quanta, USA). Their porosity was determined by Mercury Porosimetry (Quantachrome, USA) and ImageJ Analysis Software Programme (NIH, USA).

\section{Determination of cell viability}

Cytotoxicity of the sponges was tested using the L929 mouse fibroblast cell line $(16,17) .2 \times 10^{4}$ cells were seeded on 24 well plates and incubated for $24 \mathrm{~h}$ for cell attachment. CBA-C sponges were then introduced onto the cells and incubated for $48 \mathrm{~h}$. After $48 \mathrm{~h}$, the medium was removed, and $10 \%$ Alamar Blue solution in colorless DMEM $(1 \mathrm{~mL})$ was added onto the cells and incubated for one h. The optical density was measured at 570 and $595 \mathrm{~nm}$ with a microplate reader (SpectraMax M2, Molecular Devices, USA). Cell viability was determined with a calibration curve plotted from percent reductions and corresponding cell numbers (18).

\section{Proliferation of cells on CBA-C sponges}

In order to determine whether the CBA-C sponges would represent a compatible environment for cell proliferation, $2 \times 10^{4}$ DPSCs were seeded on composite sponges and subjected to osteogenic differentiation for 21 days in the differentiation medium mentioned in the previous section. In addition, $2 \times 10^{4}$ cells differentiated to osteoblastic cells were seeded on separate sponges and cultured for 21 days in McCoy's 5A maintenance medium. The media were changed every two days. On days 1, 7, 14, and 21, cell numbers on the sponges were determined by Alamar blue cell proliferation assay. DPSCs and osteoblastic cells seeded on tissue culture polystyrene (TCPS) were used as the controls of the experiment. The proliferation assay was performed in triplicate wells for each group.

\section{Calcium phosphate deposition on sponges}

To determine the calcium phosphate deposition on sponges, $2 \times 10^{4}$ DPSCs, and DPSCs differentiated to osteoblastic cells were seeded on separate CBA-C sponges. DPSCs seeded on the composite sponges were subjected to the differentiation process for 21 days. Osteoblastic cells seeded on composite sponges, on the other hand, were cultured in the maintenance medium for 21 days. At the end of the culture period, the cells on the sponges were stained with osmium tetraoxide and analyzed with SEM. For osmium tetraoxide staining, cell-seeded sponges were washed with PBS twice and fixed (4\% PFA) for 5 $\mathrm{min}$ at room temperature. The specimens were then washed with PIPES (piperazine-N, N'-bis (ethanesulfonic acid)) buffer twice and then incubated in $1 \%$ osmium tetroxide (OsO4) in PIPES buffer for one $h$ at room temperature. After a second wash with PIPES buffer, the sponges were dehydrated by incubating in a series of ethanol concentrations of $50 \%, 70 \%$, and $100 \%$ at room temperature for $5 \mathrm{~min}$. Specimens were Au-Pd coated under vacuum and examined with SEM (400F Field Emission SEM, USA).

Application and monitoring of the CBA-C sponges and mixture of collagen and BioAggregate in the experimental animals

Randomly selected ten sheeps (Akkaraman sheeps) were deprived of water for six $h$ and fasted for $18 \mathrm{~h}$ to prevent nausea and hypersalivation due to the anesthesia. On the day of the experiment, animals were weighed, and their average weight was $42 \mathrm{~kg}$. Doses of the anesthetics were determined according to the average weight of animals.

For the anesthesia, $0.1 \mathrm{mg} / \mathrm{kg}$ Alfazyne \%2 (Alfasan International B.V., Woerden, The Netherlands) containing XylazineHCl and then $5 \mathrm{mg} / \mathrm{kg}$ Ketasol 10\% (Richter Pharma AG, Wels, Austria) were applied intramuscularly in semi-membranosus and semi-tendinous regions. This dose of anesthesia did not lead to respiratory depression, and thus intubation was not necessary. Infiltrating local anesthesia was applied by using Jetokain (Adeka, Samsun, Turkey) in order to prevent the pain after the operation.

A portable dental unit system (Dynamic, China) was used for cavity preparation. Diamond carbide bur (number 10, Diatech, USA) was used for the enamel, and tungsten carbide bur (number 10, Diatech, USA) was used for the dentin layer. $1 \mathrm{~mm}$ diameter perforations were formed by using the equipments in the pulp tissues of animals under sterile conditions.

The mixture of collagen (15 mg) and BioAggregate $(1.5 \mathrm{mg})$ (CBA-M) was applied to perforated left central and lateral teeth. CBA-C sponges, on the other hand, were cut to fit the perforated area and placed on the right central and lateral teeth. Then, glass ionomer cement (Fuji IX GC, USA) was placed, and the tooth was restored by using the composite filling material (Arabesk, Voco, Germany) and two-step self-etch bonding agent (Clearfil SE Bond, Kuraray Medical, Tokyo, Japan).

Animals were randomly divided into five groups ( $n: 2)$ and were decapitated respectively in the first, second, third, fourth, and eighth weeks. Tooth samples were fixed in $10 \%$ formaldehyde (Sigma-Aldrich, Germany) and transferred for histological examination.

\section{Fixation of the teeth}

Tooth samples in formalin solution were shaken manually (1-2 $\mathrm{min}$ ) twice a day for ten days to allow better penetration of formalin solution (10\%, Sigma Aldrich, Germany) into the teeth. At the end of day 10, teeth were removed from formalin and washed with distilled water for 1-2 min. They were then placed in plastic containers.

\section{Demineralization of teeth}

After the fixation of each tooth, ethylenediaminetetraacetic acid (EDTA) based demineralization solution (30 mL; Osteosoft, Merck, Germany) was added to the container and incu- 
bated in the dark for five weeks. The solution was refreshed once a week, and each container was gently shaken (1-2 min) twice a day. The demineralization process was finalized at the end of the fifth week when the teeth became extremely flexible.

\section{Preparation of teeth for the histological section}

Teeth were placed in embedding cassettes (Isolab Embedding Cassettes, Germany), washed with tap water for several hours, and dehydrated in 70, 80, 96, and finally $99 \%$ aqueous ethanol solutions (Sigma-Aldrich, Germany). After dehydration, teeth were incubated in xylene $(4 \mathrm{~h})$ in the automatic tissue processor (Leica TP 1020). Teeth were primarily cut into two pieces along their longitudinal axes to obtain sections from pulp tissues and cavities, and then blocked with paraffin.

Ten sections ( $3 \mu \mathrm{m}$ thick) for each tooth were obtained using a rotary microtome (Leica RM 2125) and placed in the flotation bath $\left(42^{\circ} \mathrm{C}, 5-10 \mathrm{~s}\right)$ (Leica HI 1210, Germany). The slides were deparaffinized $\left(68^{\circ} \mathrm{C}\right.$ for $\left.45 \mathrm{~min}\right)$, immersed in xylene solutions (5 min, 10 times), dried, stained with hematoxylin-eosin and then dehydrated in serial aqueous alcohol solutions followed by drying at $68^{\circ} \mathrm{C}, 10 \mathrm{~min}$. Microscopic imaging and measurements were performed using Olympus BX43 Trinocular attachment Fluorescent Light Microscope and Imaging System with CellSens Standard Software. Inflammation (capillary hyperemia, inflammatory cells and fibrosis) in the pulp was evaluated qualitatively. The amount of reparative dentin was measured in the perforation area from four different points in two tooth sections (Figure 1). Eight measurements were made for each tooth sample.

\section{Statistical analysis}

Quantitative data were summarized as mean \pm standard deviation values. Since the quantitative data did not display a normal distribution with respect to the groups $(p<0.05)$, the non-parametric Kruskal-Wallis $\mathrm{H}$ test was utilized for the comparison of the study groups. Significant differences among the groups were determined with the Kruskal-Wallis $\mathrm{H}$ test $(p<0.05)$, pairwise comparisons of

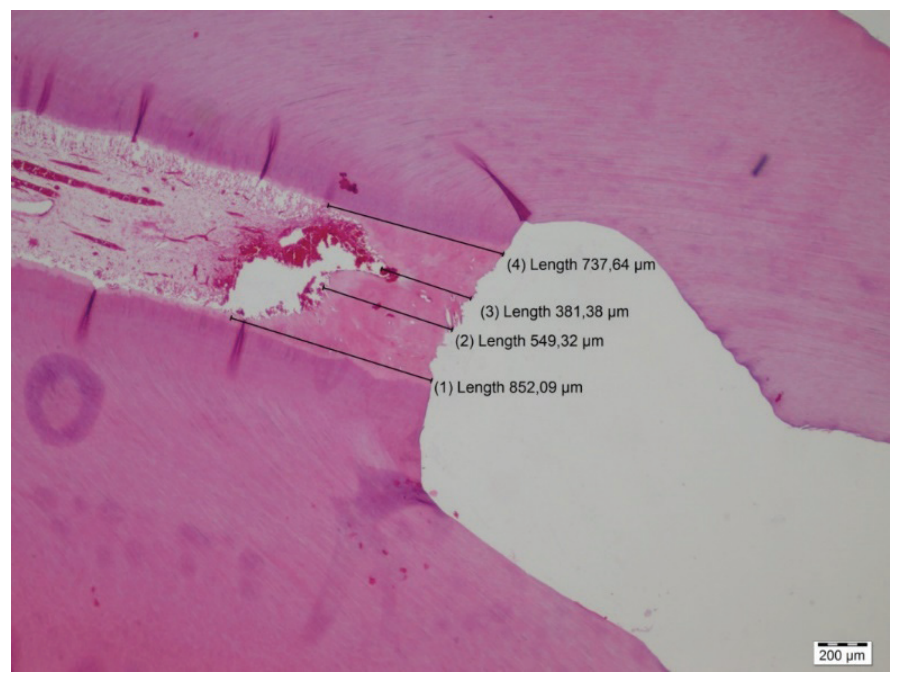

reparative dentin thickness were performed through the posthoc Bonferroni test $(p<0.05)$. The same time periods of the materials were compared via the Mann Whitney $U$ test. SPSS version 13.0 for Windows (SPSS, Inc., IL, USA) was employed for all analyses. The level of statistical significance was set at $p<0.05$.

\section{Results}

\section{DPSCs isolation and characterization}

Stem cells were isolated from sheep dental pulp by using the outgrowth method (Figure 2). The cells were visualized using phase-contrast microscopy and were examined with flow cytometry for their stem cell markers. The cells were found to be negative for hematopoietic stem cell marker CD 34 and positive for the mesenchymal stem cell marker CD 44 $(15,19)$ (Figure 2).
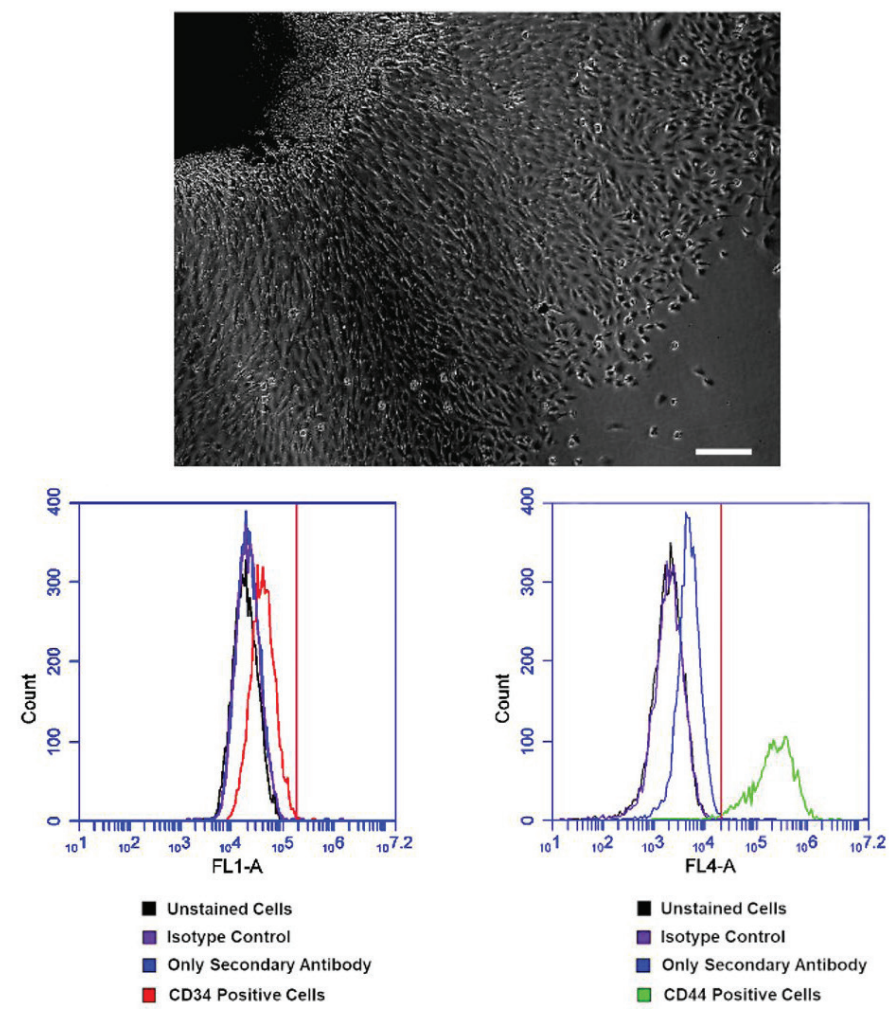

Figure 2. Outgrowth of DPSCs from minced pulp tissue at the end of week 1 (top). Flow cytometry analysis of isolated DPSCs (bottom). Scale bar: $200 \mu \mathrm{m}$.

Osteogenic differentiation of the isolated cells into an osteoblastic cell lineage

The isolated DPSCs were subjected to osteogenic differentiation for 21 days in an induction medium containing ascorbic acid, dexamethasone, and $\beta$-glycerophosphate (20). On days 7 and 21 of osteogenic induction, Alizarin Red staining was performed to visualize the calcium phosphate minerals deposited by the cells as an indicator of osteogenic differentiation (Figure 3). It was observed that induction of 21 days was satisfactory for calcium deposition and thus differentiation.

Figure 1. Quantification of reparative dentin thickness. 

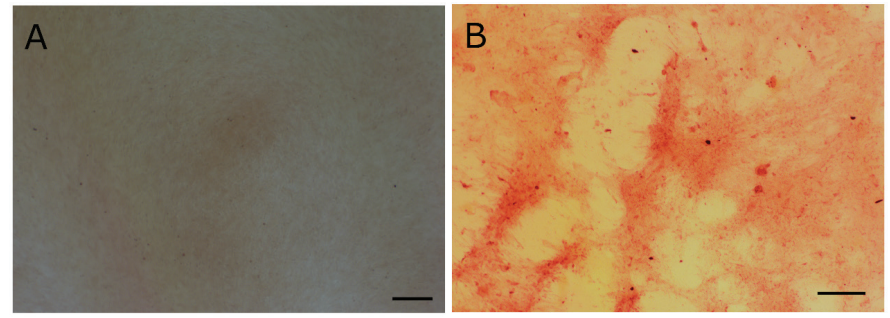

Figure 3. Alizarin Red staining of DPSCs in osteogenic differentiation. A) 7 days, B) 21 days post osteogenic induction. Scale bar: $200 \mu \mathrm{m}$.

\section{Characterization of pure collagen and CBA-C sponges}

The surface characteristics of pure lyophilized collagen and CBA-C sponges were examined with SEM (Figure 4). It was observed that both pure and the composite sponges are highly porous. The addition of BioAggregate did not affect the formation of the highly porous structure of the composite sponges, but the level of porosity was significantly decreased upon BioAggregate addition.

The porosity of the sponges was measured using mercury porosimetry and calculated from the SEM micrographs by using ImageJ software. It was observed that the addition of BioAggregate resulted in a decrease of porosity (reduced from $86 \%$ to $59 \%$ ) when measured with the mercury porosimeter (Table 1). On the other hand, analysis of SEM micrographs by using Image J software indicated that the collagen sponge's porosity was $62 \%$ and decreased to $36 \%$ upon BioAggregate in a corporation.

Pore size distributions of pure and composite collagen sponges obtained from SEM micrographs are presented in Figure 5. It was observed that the pure collagen sponge has a higher fraction of larger pores than the CBA-C sponge.

\section{Alamar blue cell viability test}

In order to study the cell viability directly by Alamar Blue cell viability test, L929 mouse fibroblast cells were seeded on
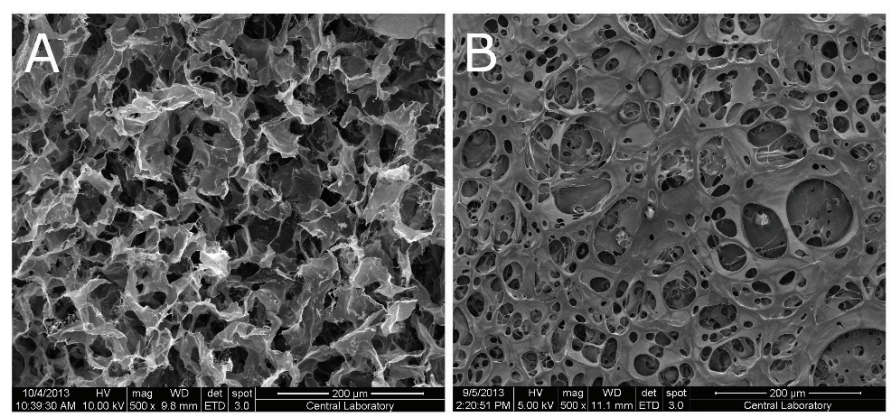

Figure 4. SEM micrographs of collagen-based sponges. A) Pure collagen, B) Collagen-BioAggregate (10:1, w/w) composite sponge.

Table 1. Porosity of the sponges measured with two different methods.

Porosity (\%)

\begin{tabular}{lcc}
\cline { 2 - 3 } Sample & Mercury Porosimetry & SEM \\
\hline $\begin{array}{l}\text { Pure Collagen } \\
\text { Sponge }\end{array}$ & 86 & 62 \\
\hline CBA-C Sponge & 59 & 36 \\
\hline
\end{tabular}



Figure 5. Pore size distribution of the Collagen and CBA-C sponge as determined by using ImageJ using SEM micrographs.

TCPS wells, and then pure and composite collagen sponges were placed on top. It was found that the percent viability of cells in the wells where collagen sponges are placed were $70 \%$ and $65 \%$ with pure collagen and CBA-C sponges, respectively. The viability was less than TCPS control with no sponge (Table 2); however, they are not significantly lower than the 70\% limit indicated in ISO10993-5 as the limit of non-cytotoxicity.

Table 2. Cell viability after $48 \mathrm{~h}$ of direct contact with the sponges, *seeded cell density $2 \times 10^{4}$ cells/well.

\begin{tabular}{lcc}
\hline Sample Type & Cell Number* & Viability (\%) \\
\hline TCPS control & $204,000 \pm 7000$ & 100 \\
\hline Pure Collagen Sponge & $142,000 \pm 500$ & 70 \\
\hline CBA-C Sponge & $133,000 \pm 9500$ & 65 \\
\hline
\end{tabular}

\section{Proliferation of DPSCs and osteoblastic cells on CBA-C sponges}

The biocompatibility of CBA-C sponges was studied by Alamar Blue cell proliferation assay. For this study, both the DPSCs and osteoblastic cells were seeded on the sponges, and the proliferation of cells on sponges was compared with the cells on TCPS (Figure 6 ).

It was observed that both stem cells and osteoblastic cells proliferated on composite sponges for 21 days; however, it was also found that the proliferation rates of both

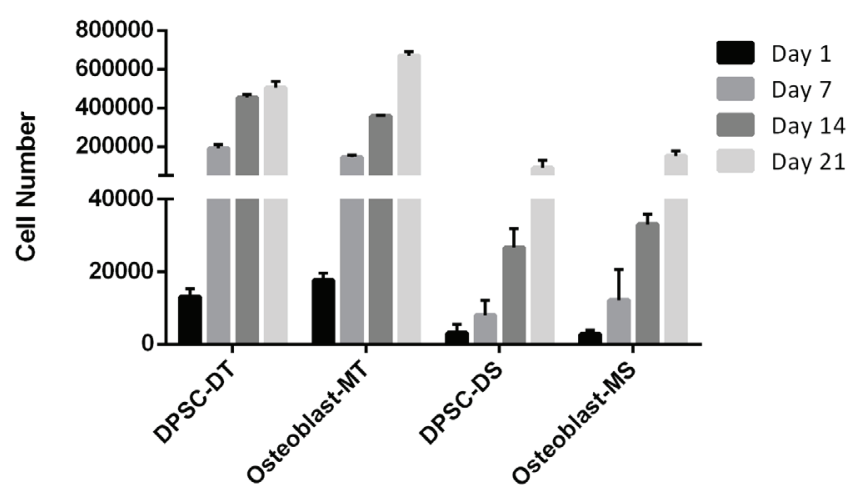

Figure 6. Proliferation of DPSCs and osteoblastic cells during culture on CBA-C sponge. DPSC-DT: DPSCs in differentiation medium on TCPS; Osteoblasts-MT: Osteoblasts in maintenance medium on TCPS; DPSC$D S$ : DPSCs in differentiation medium on CBA-C sponge; Osteoblast-MS: Osteoblasts in maintenance medium on CBA-C sponge. 
cell types were lower than the cells on TCPS, probably due to the smaller area of the sponges in comparison to TCPS surface. In addition, at the end of 21 days, the number of cells in the differentiation group (DPSC-DS) was found to be lower than that of the osteoblast maintenance group both on TCPS and on sponges (Osteoblast-MT and Osteoblast-MS; respectively).

\section{Calcium phosphate deposition on CBA-C sponges}

Figure 7 shows the SEM micrographs of cells on CBA-C sponges after 21 days of culture. For this study, DPSCs were seeded on the composite sponges and differentiated for 21 days. In addition, osteoblastic cells were seeded on separate composite sponges and cultured in a maintenance medium for 21 days. At the end of 21 days of culture, the sponges were subjected to energy dispersive X-ray analysis (EDX). Deposition of calcium and phosphate elements was observed on CBA-C sponges for both cell types.
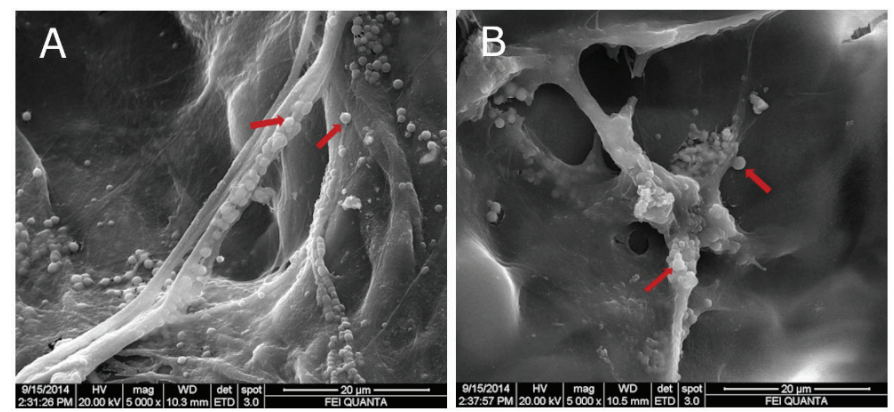

Figure 7. SEM micrographs of cells on CBA-C sponge after 21 days of culture. A) DPSCs in differentiation medium, B) osteoblastic cells in maintenance medium. Arrows point at the calcium phosphate minerals on the composite structure.

\section{Histopathological findings of dental samples}

Phenotypic characteristics of cells found in reparative dentin tissue in CBA-C sponges and CBA-M applied groups were not different.

\section{Week 1}

During the observations at the end of week 1, bleeding was observed in teeth for both CBA-C sponges and CBA-M applied groups. There was no reparative dentin tissue formation in the perforated area.

\section{Week 2}

In the CBA-C sponges applied group, the reparative dentin tissue formation was started and vascularized fibrous tissue formation was observed in the perforated area. However, hyperemia and porous structured reparative dentin tissue were observed in the pulp tissue in the CBA-M applied group.

\section{Week 3}

In the CBA-C sponges applied group, the reparative dentin tissue was formed, but there was a hyperemic porous structure towards the perforated area and in the CBA-M applied group, reparative dentin tissue properly proceeded inside the pulp tissue.

\section{Week 4}

At the end of the fourth week, the CBA-C sponges applied group showed less porous reparative dentin tissue than third week, and there were residues of a composite scaffold in the reparative dentin tissue (Figure 8). Except for capillary hyperemia, there was no sign of inflammation in the pulp tissue such as neutrophils, macrophages and lymphocytes infiltrations (Figure 8). In the CBA-M applied group, reparative dentin tissue occupied a large portion of the pulp tissue and necrotic tissues were observed in the perforated area.



Figure 8. Light microscopy image of Hematoxylin-Eosin stained tooth sample of CBA-C sponge applied group (week 4). Residual composite sponge (black arrow) and hyperemic areas (white arrows) (4X magnification).

\section{Week 8}

In the CBA-C sponges applied group, complete, homogenous, and compact reparative dentin tissue observed in the perforated area and there were residues of composite sponge in reparative dentin area. The capillary hyperemia was seen in the same area. Integration of the existing dentin tissue with reparative dentin tissue was also observed (Figure 9). In the CBA-M applied group, on the other hand, necrotic tissue residues and hyperemia was observed (Figure 10).

Reparative dentin thicknesses measurements

The mean reparative dentin thicknesses are presented in Table 3. It is observed that reparative dentin tissue formation started on week 2 in both CBA-C sponges and CBA-M applied groups.

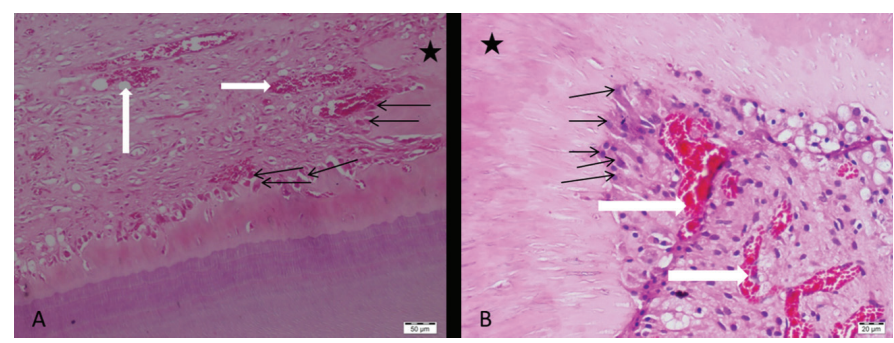

Figure 9. Light microscopy images of Hematoxylin-Eosin stained tooth sample of CBA-C sponge applied group (week 8). Reparative dentin tissue (black stars), odontoblast-like cells (black arrows), and hyperemic areas (white arrows) (A:20X magnification, B: 40X magnification). 


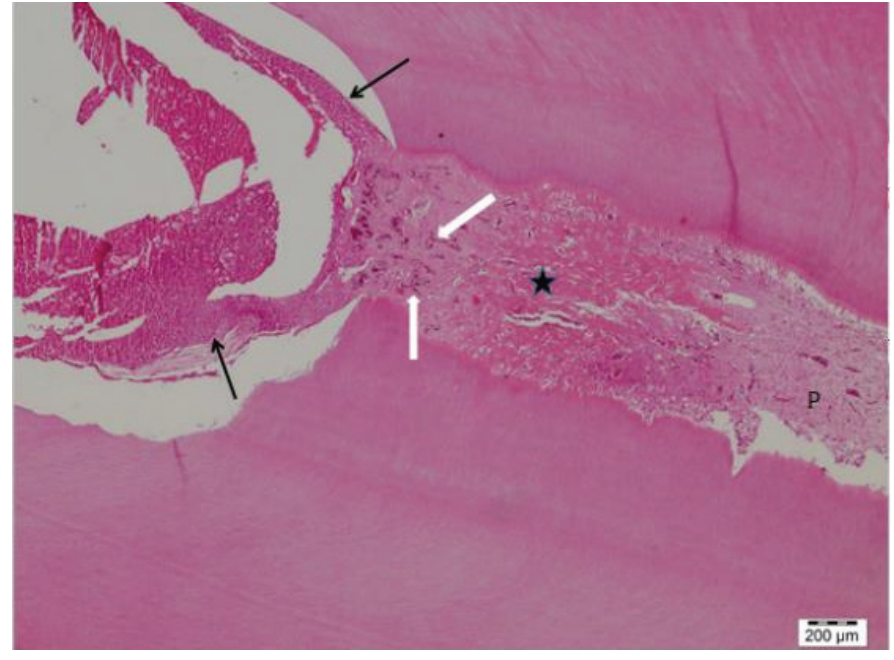

Figure 10. Light microscopy image of Hematoxylin-Eosin stained tooth sample of CBA-M applied group (week 8). Necrotic tissues (black arrows), hyperemic areas (white arrows), reparative dentin tissue (black stars) and pulp (P) (4X magnification).

Table 3. Descriptive values of reparative dentin thicknesses with

respect to the time periods. Dentin Tissue Thickness were presented

as Mean \pm Std Dev. $(\mu \mathrm{m})$; *: Kruskal Wallis H test; $a, b, c, A, B, C$ :

Different superscripts in the rows show a significant difference

(Bonferroni test; $p<0.05)$; **: Mann Whitney U test.

\begin{tabular}{lccccc}
$\begin{array}{l}\text { Time periods } \\
\text { Materials }\end{array}$ & $\mathbf{2}$ & $\mathbf{3}$ & $\mathbf{4}$ & $\mathbf{8}$ & $\boldsymbol{p}^{*}$ \\
\cline { 1 - 5 } $\begin{array}{l}\text { CBA-C } \\
(\boldsymbol{\mu m})\end{array}$ & $1339 \pm 487^{\mathrm{a}}$ & $1881 \pm 267^{\mathrm{b}}$ & $1905 \pm 552^{\mathrm{b}}$ & $1951 \pm 565^{\mathrm{b}}$ & $<0.05$ \\
$\begin{array}{l}\mathbf{C B A}-\mathbf{M} \\
(\boldsymbol{\mu m})\end{array}$ & $1253 \pm 104^{\mathrm{A}}$ & $2227 \pm 393^{\mathrm{B}}$ & $2759 \pm 318^{\mathrm{C}}$ & $2869 \pm 455^{\mathrm{C}}$ & $<0.05$ \\
\hline $\boldsymbol{p}^{* *}$ & 0.955 & $<0.001$ & $<0.001$ & $<0.001$ & \\
\hline
\end{tabular}

For the CBA-C sponges applied group, the differences were determined between week 2 and weeks $3,4,8(p<0.05)$. In contrast, the other pairwise comparisons were not significant $(p>0.05)$. Significant differences were found in reparative dentin thicknesses of the CBA-M applied group between the week 2 and weeks 3, 4, 8, and week 3 and weeks 4 , 8 ( $p<0.05)$; but not between weeks 4 and 8 ( $p>0.05)$. As the same time periods of the CBA-C sponges and CBA-M applied groups were compared, significant differences were identified in the comparisons of 3,4 , and 8 weeks $(p<0.001)$. However, a similar comparison was not significant for week 2 of the CBA-C sponges, and CBA-M applied groups ( $p=0.955)$.

\section{Discussion}

The aim of direct pulp capping is to ensure the continuity of the tooth pulp tissue vitality. This can be achieved by using biocompatible dental materials and induce reparative dentin formation, prevent bacterial infections of the pulp, and ensure the repair of the vital pulp tissue. Recently, studies are carried out on regenerative dentistry practices in pulp capping. Regenerative dentistry focuses on scaffold-based or scaffold-free strategies (21). The use of growth factors and biological molecules with scaffolds as a pulp capping material increases the success of direct pulp capping treatment (22). In this study, collagen and biocompatible BioAggregate materials were either used in the form of composite sponges $(C B A-C)$ as a scaffolding material or as a mixture (CBA-M) and were compared for their effectiveness in the induction of reparative dentin formation.

For this study, DPSCs were used because it is known that DPSCs exhibit mesenchymal stem cell properties and are reported to be multipotent stem cells that can differentiate into osteoblastic cells, including osteoblasts and especially odontoblasts, in addition to other cell types such as adipocytes and neural cells $(13,23,24)$. There are still unknowns about the potential and the behavior of the dental pulp progenitor/stem cells (12). The cells isolated from the pulp tissue were, therefore, examined with flow cytometry and found to be positive for mesenchymal stem cell marker CD 44 (15) (Figure 2). After this proof that the isolated cells belong to mesenchymal stem cell lineage, they were then subjected to osteoblastic differentiation. The differentiation towards odontoblasts is similar to osteogenic differentiation, which starts with an increase in ALP expression and is followed by mineralization (20). Within 21 days of induction in the osteogenic differentiation medium, the isolated DPSCs could deposit calcium phosphate minerals, indicating that the cells could differentiate into osteoblastic lineage (Figure 3).

The sponges used in this study were characterized in terms of their porosities, pore size distributions, and cytocompatibilities. The porosity of the sponges was studied both by mercury porosimetry and the surface topography obtained from SEM (Table 1). The lower porosity values obtained from SEM micrographs might be due to the differences in the measurement techniques. In mercury porosimetry, pressure is used, so mercury penetrates deep into the sample (25), while in SEM analysis, only the images of the surface of the sponges are visualized and used for the analysis of porosity. The pore size distribution of the sponges was also analyzed by using the SEM micrographs (Figure 5). It was observed that the CBA-C sponge has a high fraction of smaller pores than the pure collagen sponge. The presence of inorganic material BioAggregate probably physically blocks the pores decreasing the porosity and lowering the average pore size.

The cytocompatibility of CBA-C sponges was shown in the L929 mouse fibroblast cell line by using a direct contact approach (Table 2). The slight reduction in the cell number on both pure collagen and CBA-C sponges, compared to TCPS control, might be either due to the weight applied by the sponges onto the cells or the migration of cells on TCPS into the sponges. In addition, the presence of the sponges on top of the cells may have blocked the diffusion of the culture medium towards the cells underneath the sponge, thus leading to the death of these undernourished cells. Furthermore, the number of live cells in contact with either pure collagen or CBA-C sponges is very similar, indicating that BioAggregate does not have a negative effect on the cytocompatibility of the composite.

The proliferation of DPSCs and osteoblastic cells on the composite sponges were also studied (Figure 6). Both cell types could proliferate on the sponges. The lower number of cells in the differentiation group (DPSC-DS) compared to the osteoblast maintenance groups (Osteoblast-MT and Osteoblast-MS) might be due to the reduced proliferation rate of the stem cells during the differentiation phase (26). The DPSCs seeded on the sponges were able to differentiate to 
osteogenic lineage and deposit calcium phosphate minerals (Figure 7) with comparable Ca:P ratios deposited by osteoblastic cells maintained on the sponges for 21 days.

It is known that BioAggregate is not cytotoxic, and it can induce odontoblastic differentiation of tooth pulp stem cells and mineralization under in vitro conditions (27-30). In this study, untreated teeth (not used in the experimental groups) of animals were collected, and stem cells were isolated from their pulp tissues. After the differentiation process, osteoblastic cells were seeded on the CBA-C sponges. After 21 days of incubation on the sponges, calcium phosphate deposition was observed on the sponges.

BioAggregate, being a biocompatible cement, can be used in endodontic fillings and repair (31). In a study, the effect of four different materials, including BioAggregate and ProRoot MTA, on odontogenic differentiation of human tooth pulp cells were studied (32). It was found that samples with ProRoot MTA and BioAggregate both presented the ALP activity. ALP is an indicator of early osteoblastic differentiation and has important roles in the mineralization process. However, more mineralized nodules were observed with BioAggregate used samples than with ProRoot MTA samples at the end of the $14^{\text {th }}$ day $(32,33)$. Another study showed that at the end of the 4 th week MTA, Biodentine and BioAggregate induced adequate reparative dentin formation in rat pulps (34). Similarly, in our study, it was observed that both CBA-C sponges and CBA-M led to osteodentin formation, which showed similar mineralization as the dentin tissue of the tooth 2 weeks post-implementation.

In another study, the biocompatibility of MTA and BioAggregate was evaluated. The materials were produced in line with the producer's instructions, placed in Teflon plates, and implanted in the back of the rats. Rats were sacrificed on the $7^{\text {th }}$ and $30^{\text {th }}$ days, and kidney and liver samples were histologically and morphologically examined. It was found that MTA and BioAggregate caused inflammation in the kidney and liver and that MTA had a higher inflammatory effect than BioAggregate (35). Morais et al. and Parirokh et al. specified that the inflammatory response of the subcutaneous tissue against MTA reduced after 60 days. However, it was not clearly stated whether there was complete healing compared to the control group $(36,37)$. In our study, no inflammatory response was observed except for capillary hyperemia.

It is known that type I collagen is the main extracellular matrix protein of the pulp and dentin matrix (38). It also has important roles in the adhesion and proliferation of cells (39). Jang et al. investigated the effect of gelatin- and fibrin-based hemostatic hydrogels as a scaffold in regenerative endodontics therapy. Gelatin is a collagen based biopolymer protein. And they reported that significantly higher cell viability was observed at the gelatin-based scaffolds group when compared with the fibrin-based scaffolds group (40). We, therefore, used type I collagen as the other component of our sponges.

Kakarla et al. (41) used collagen particles impregnated with antibiotics and Pulpotec ${ }^{\circledR}$ cement as a capping material in deciduous (baby) teeth. The histological examinations revealed that inflammation was reduced in both groups on days 7 and 15. At the end of day 30, no inflammation was observed, and the dentin bridge was formed. Furthermore, it was observed that the collagen structure was a better capping material compared to the Pulpotec cement. In another study collagen based scaffolds, which contain polyethyleneimine (PEI) - bonemorphogenic protein-2 (pBMP-2) and/or fibroblast growth factor-2 ( $p F G F-2$ ) nanoplexes increased cell proliferation, expression levels of BMP-2 and FGF-2, and mineralization when compared to ProRoot- MTA group (42). Similarly, in our study, there were tubule-like structures similar to the osteodentin structure of natural dentin tissue in some samples of CBA-C sponges applied group on week 8. In addition, new tissue formation was observed within some samples of CBA-C sponges applied group on week 8, and this was due to the attachment and penetration of surrounding cells into the sponge, as was also reported in other in vitro studies (43).

Dick and Carmichael (44) evaluated the effectiveness of collagen sponge as a capping material and observed that the collagen sponge did not result in a thick dentin bridge formation, but it presented mineralization. In our study at the end of Week 8, the dentin was more compact in the CBA-C sponges applied group, and reparative dentin tissue formation was thicker in the CBA-M applied group. However, necrotic tissue residues seen in the perforation area in the CBA-M applied group may prepare the ground for bacterial infiltration by resorption.

In a clinical study, the effect of dental pulp stem/progenitor cells and collagen sponge on the healing of the human mandible was examined. These cells were isolated from one of the lower third molar teeth of patients. The cells were seeded on the collagen sponge and then placed in the tooth extraction gap. The third molar tooth, which was in the opposite direction, was used as the control sample with no intervention. Dental pulp stem/progenitor cells on the collagen sponges started bone regeneration after three months. According to the radiography results, the cortical bone level was higher in the experimental group compared to the control sample. After one year, a well-organized bone structure was observed in the intervention area, which was shown by radiographic and histological examinations and immunoflourescent microscopy (45). In our study, the histological examinations revealed that after 8 weeks, the perforation area was entirely recovered by the osteodentin structure in both groups; however, in CBA-M, applied group necrotic tissue residues were observed in the cavitation area.

The results of this study show that the collagen-BioAggregate sponges have a porous structure, which is important for the integration and maintenance of cells. The sponges were found to be biocompatible with both DPSCs and osteoblastic cells, and the DPSCs seeded on the sponges can differentiate into the osteoblastic lineage and deposit calcium phosphate mineral. And the histopathological findings of our study showed that collagen-BioAggregate sponges could provide reparative dentin formation more ideally compared to the mixture of collagen-BioAggregate.

\section{Conclusion}

CBA-C sponge represents a better microenvironment for reparative dentin formation probably due to maintaining DPSCs and allowing their osteogenic differentiation and thus calcium phosphate deposition. Adding spongy struc- 
ture to pulp capping materials can increase success in direct pulp capping treatments.

Türkçe Özet: Kolajen-bioaggregate kompozit yapı iskelesinin koyun pulpa dokusunun tamirinde değerlendirilmesi. Amaç: Bu çalışmada kolajen-BioAggregate karışımı (CBA-M) ve yapı iskelesi malzemesi olarak kolajen-BioAggregate kompozit (CBA-C) süngerin dentin tamiri üzerindeki etkilerinin karşılaştırılması amaçlanmıştır. Gereç ve Yöntem: Oluşturulan CBA-C sünger (10:1 w/W) Taramalı Elektron Mikroskopu (SEM) ve Civa Porozimetrisi ile karakterize edildi ve CBA-C süngerin L929 fare fibroblast hücre hattı üzerindeki sitotoksik etkisi incelendi. Koyun diş pulpa dokusundan diş pulpa kök hücreleri (DPSCler) izole edildi ve mezenkimal kök hücre belirleyicisi olan CD44 ekspresyonunu incelemek için akış sitometrisi kullanıldı. İzole edilen DPSCler' in osteojenik farklılaşma düzeyi Alizarin kırmızısı ile boyanarak değerlendirildi. CBA-C süngerin biyouyumluluğu, hücre çoğalması ve hücrelerin kalsiyum fosfat biriktirebilmeleri açısından incelendi. CBA-C sünger ve $C B A-M$ ' nin dentin rejenerasyonunu indükleyici etkisi perfore edilen koyun diş pulpalarında sekiz haftalık zaman aralığında incelendi ve uygun istatistiksel yöntemlerle analizler değerlendirildi. Bulgular: CBA-C süngerin DPSCler için biyouyumlu olduğu sonucuna varıldı. CBA-C sünger üzerine ekilen DPSCler osteoblastik kökene farklılaştı ve in vitro koşullarda kalsiyum fosfat kristalleri çökelmesi gözlendi. CBA-C sünger uygulanan grupta iki hafta sonra tamir dentini oluşumu gözlendi. Sekiz haftanın sonunda CBA-C sünger uygulanan grupta tamamlanmış tamir dentini oluşumu gözlenirken, CBA-M uygulanan grupta nekrotik doku artıkları gözlendi. Sonuç: CBA-C sünger, DPSCler' in sürekliliğine, osteojenik farklılaşmasına ve dolayısıyla kalsiyum fosfat birikimine izin vermesiyle tamir dentini oluşumu için iyi bir ortam sunmuştur. Anahtar kelimeler: Direkt pulpa kuafaj, tamir dentini, kolajen sünger, BioAggregate, BioAggregate-sünger kompozit.

Ethics Committee Approval: All the surgical procedures were approved by the Animal Testing Ethics Committee of Firat University, Elazığ, Turkey, with meeting number 2014/9 and decree number 96.

Informed Consent: Not required.

Peer-review: Externally peer-reviewed.

Author contributions: $\mathrm{MY}, \mathrm{VH}$ participated in designing the study. $\mathrm{BD}, \mathrm{DSB}, \mathrm{HE}, \mathrm{MY}, \mathrm{VH}$ participated in generating the data for the study. $B D, D S B, H E$ participated in gathering the data for the study. BD, DSB, $\mathrm{HE}, \mathrm{MY}$ participated in the analysis of the data. BD, DSB wrote the majority of the original draft of the paper. $B D, D S B, H E, V H$ participated in writing the paper. $\mathrm{BD}, \mathrm{DSB}, \mathrm{HE}, \mathrm{MY}, \mathrm{VH}$ have had access to all of the raw data of the study. $B D, D S B, H E, M Y, V H$ have reviewed the pertinent raw data on which the results and conclusions of this study are based. $\mathrm{BD}, \mathrm{DSB}, \mathrm{HE}, \mathrm{MY}, \mathrm{VH}$ have approved the final version of this paper. BD guarantees that all individuals who meet the Journal's authorship criteria are included as authors of this paper.

Conflict of Interest: The authors had no conflict of interest to declare.

Financial Disclosure: This work was funded by the Scientific and Technological Research Council of Turkey (TÜBITAK), Grant No: 112 S584 and by the Research Fund of the Inonu University, Project Number: 2013/80.

Acknowledgement: The authors acknowledge BIOMATEN, the Middle East Technical University Center of Excellence in Biomaterials and Tissue Engineering for the use of the facilities.

\section{References}

1. Fuks $A B$. Vital pulp therapy with new materials for primary teeth: new directions and treatment perspectives. Pediatr Dent 2008;30:211-9. [CrossRef]

2. Dammaschke T. The history of direct pulp capping. J Hist Dent 2008;56:9-23.
3. Briso ALF, Rahal V, Mestrener SR, Dezan Junior E. Biological response of pulps submitted to different capping materials. Braz Oral Res 2006;20:219-25. [CrossRef]

4. Torabinejad $M$, White DJ, inventors. Tooth filling material and method of use. patent United States Patent \& Trademark Office 5,415,547. 1995.

5. Komobayashi T, Zhu Q, Eberhart R, Imai Y. Current status of direct pulp-capping materials for permanent teeth. Dental Mat J 2016;35:1-12. [CrossRef]

6. Suh B, Cannon M, Yin R, Martin D (2008) Polymerizable dental pulp healing, capping, and lining material and method for use. International Patent A61K33/42;A61K33/42 Application number WO2008US5438720080220; Publication number WO2008103712 (A2); Publication date 2008-08-28

7. Park J-W, Hong S-H, Kim J-H, Lee S-J, Shin S-J. X-Ray diffraction analysis of white ProRoot MTA and Diadent BioAggregate. Oral Surg Oral Med Oral Pathol Oral Radiol Endod 2010;109:155-8. [CrossRef]

8. Scheller E, Krebsbach P, Kohn D. Tissue engineering: state of the art in oral rehabilitation. J Oral Rehabil 2009;36:368-89. [CrossRef]

9. Rosa V, Della Bona A, Cavalcanti BN, Nör JE. Tissue engineering: from research to dental clinics. Dent Mater 2012;28:341-8. [CrossRef]

10. Demarco FF, Conde MCM, Cavalcanti BN, Casagrande L, Sakai VT, Nör JE. Dental pulp tissue engineering. Braz Dent J 2011;22:313. [CrossRef]

11. Freyman T, Yannas I, Gibson L. Cellular materials as porous scaffolds for tissue engineering. Prog Mater Sci 2001;46:273-82. [CrossRef]

12. Sloan Alastair J, Waddington Rachel J. Dental pulp stem cells: what, where, how?. Int J Paediatr Dent 2009;19:61-70. [CrossRef]

13. Lan X, Sun Z, Chu C, Boltze J, Li S. Dental pulp stem cells: an attractive alternative for cell therapy in ischemic stroke. Front Neurol 2019;10:824. [CrossRef]

14. Van De Loosdrecht AA, Alhan C, Béné MC, et al. Standardization of flow cytometry in myelodysplastic syndromes: report from the first European LeukemiaNet working conference on flow cytometry in myelodysplastic syndromes. Haematologica 2009;94:1124-34. [CrossRef]

15. Yang $\mathrm{M}-\mathrm{C}$, Chi $\mathrm{N}-\mathrm{H}$, Chou N-K, et al. The influence of rat mesenchymal stem cell CD44 surface markers on cell growth, fibronectin expression, and cardiomyogenic differentiation on silk fibroin-hyaluronic acid cardiac patches. Biomaterials 2010;31:854-62. [CrossRef]

16. Shiau M-Y, Chiou H-L, Lee Y-L, Kuo T-M, Chang Y-H. Establishment of a consistent L929 bioassay system for TNF-alpha quantitation to evaluate the effect of lipopolysaccharide, phytomitogens and cytodifferentiation agents on cytotoxicity of TNF-alpha secreted by adherent human mononuclear cells. Mediators Inflamm 2001;10:199. [CrossRef]

17. Miranda RB, Fidel SR, Boller MAA. L929 cell response to root perforation repair cements: an in vitro cytotoxicity assay. Braz Dent J 2009;20:22-6. [CrossRef]

18. Al-Nasiry S, Geusens N, Hanssens M, Luyten C, Pijnenborg R. The use of Alamar Blue assay for quantitative analysis of viability, migration and invasion of choriocarcinoma cells. Hum Reprod 2007;22:1304-9. [CrossRef]

19. Gronthos S, Mankani M, Brahim J, Robey PG, Shi S. Postnatal human dental pulp stem cells (DPSCs) in vitro and in vivo. Proc Natl Acad Sci 2000;97:13625-30. [CrossRef]

20. Wang J, Liu B, Gu S, Liang J. Effects of Wnt/ $\beta$-catenin signalling on proliferation and differentiation of apical papilla stem cells. Cell Prolif 2012;45:121-31. [CrossRef]

21. Dissanayaka WL, Zhang C. Scaffold-based and scaffold-free strategies in dental pulp regeneration. J Endod 2020;46:81-9. [CrossRef]

22. Okamoto M, Matsumoto $S$, Sugiyama A, et al. Performance of a biodegradable composite with hydroxyapatite as a scaffold in pulp tissue repair. Polymers 2020;12:937. [CrossRef] 
23. Komori T. Regulation of osteoblast and odontoblast differentiation by Runx2. J Oral Biosci 2010;52:22-5. [CrossRef]

24. Liu M, Sun Y, Liu Y, Yuan M, Zhang Z, Hu W. Modulation of the differentiation of dental pulp stem cells by different concentrations of $\beta$-glycerophosphate. Molecules 2012;17:121932. [CrossRef]

25. Moore MJ, Jabbari E, Ritman EL, et al. Quantitative analysis of interconnectivity of porous biodegradable scaffolds with microcomputed tomography. J Biomed Mater Res A 2004;71:258-67. [CrossRef]

26. Cooper G, Hausman R. The cell: a molecular approach. Sinauer Associates, Sunderland, MA;2000.

27. Zhang S, Yang X, Fan M. BioAggregate and iRoot BP Plus optimize the proliferation and mineralization ability of human dental pulp cells. Int Endod J 2013;46:923-9. [CrossRef]

28. Jung JY, Woo SM, Lee BN, Koh JT, Nör J, Hwang YC. Effect of Biodentine and Bioaggregate on odontoblastic differentiation via mitogen-activated protein kinase pathway in human dental pulp cells. Int Endod J 2015;48:177-84. [CrossRef]

29. Yan P, Yuan Z, Jiang H, Peng B, Bian Z. Effect of bioaggregate on differentiation of human periodontal ligament fibroblasts. Int Endod J 2010;43:1116-21. [CrossRef]

30. Yuan Z, Peng B, Jiang H, Bian Z, Yan P. Effect of bioaggregate on mineral-associated gene expression in osteoblast cells. J Endod 2010;36:1145-8. [CrossRef]

31. Saghiri MA, Asatourian A, Garcia-Godoy F, Gutmann JL, Sheibani N. The impact of thermocycling process on the dislodgement force of different endodontic cements BioMed Res Int 2013;2013.

32. Chang S-W, Lee S-Y, Kum K-Y, Kim E-C. Effects of ProRoot MTA, Bioaggregate, and Micromega MTA on odontoblastic differentiation in human dental pulp cells. J Endod 2014;40:1138. [CrossRef]

33. Cormier C. Markers of bone metabolism. Curr Opin Rheumatol 1995; 7: 243-8. [CrossRef]

34. Kim J, Song YS, Min KS, et al. Evaluation of reparative dentin formation of ProRoot MTA, Biodentine and BioAggregate using micro-CT and immunohistochemistry. Restor Dent Endod 2016;41:29-36. [CrossRef]
35. Khalil W, Eid N. Biocompatibility of BioAggregate and mineral trioxide aggregate on the liver and kidney. Int Endod J 2013;46:730-7. [CrossRef]

36. de Morais $\mathrm{CAH}$, Bernardineli N, Garcia RB, Duarte MA, Guerisoli DM. Evaluation of tissue response to MTA and Portland cement with iodoform. Oral Surg Oral Med Oral Pathol Oral Radiol Endod 2006;102:417-21. [CrossRef]

37. Parirokh M, Mirsoltani B, Raoof M, Tabrizchi $H$, Haghdoost A. Comparative study of subcutaneous tissue responses to a novel root-end filling material and white and grey mineral trioxide aggregate. Int Endod J 2011;44:283-9. [CrossRef]

38. Ravindran S, Huang C-C, George A. Extracellular matrix of dental pulp stem cells: applications in pulp tissue engineering using somatic MSCs. Front Physiol 2014;4:395. [CrossRef]

39. Wu C-C, Huang S-T, Lin H-C, Tseng T-W, Rao Q-L, Chen M-Y. Expression of osteopontin and type I collagen of hFOB 1.19 cells on sintered fluoridated hydroxyapatite composite bone graft materials. Implant Dent 2010;19:487-97. [CrossRef]

40. Jang JH, Moon JH, Kim SG, Kim SY. Pulp regeneration with hemostatic matrices as a scaffold in an immature tooth minipig model. Sci Rep 2020;10:12536. [CrossRef]

41. Kakarla P, Avula JSS, Mellela GM, Bandi S, Anche S. Dental pulp response to collagen and pulpotec cement as pulpotomy agents in primary dentition: A histological study. J Conserv Dent 2013;16:434. [CrossRef]

42. Chakka LRJ, Vislisel J, Vidal CMP, Biz MT, Salem AK, Cavalcanti BN. Application of BMP-2/FGF-2 gene-activated scaffolds for dental pulp capping. Clin Oral Investig 2020;24:4427-4437. [CrossRef]

43. Doğan A, Munkley A, Thomas S, Moran J. Microscopic evaluation of biocompatibility of osteoblast impregnated human collagen sponges. J Dent Res 1992;71:637.

44. Dick H, Carmichael D. Reconstituted antigen-poor collagen preparations as potential pulp-capping agents. J Endod 1980;6:641-4. [CrossRef]

45. d'Aquino R, De Rosa A, Lanza V, et al. Human mandible bone defect repair by the grafting of dental pulp stem/progenitor cells and collagen sponge biocomplexes. Eur Cell Mater 2009;18:7583. [CrossRef] 